\title{
A case series of Factor $V$ Leiden mutation in pregnancy
}

\author{
J Bailly, ${ }^{1,2}$ MB ChB, Dip PEC (SA), MMED (Haem), FCPath (SA) Haem; B F Jacobson, ${ }^{3,4}$ MB ChB, FRCS (Glasgow), PhD (Med), \\ MMed (Haem), FCPath (SA) Haem; S Louw, ${ }^{3,4}$ MB ChB, MMed (Haem), FCPath (SA) Haem \\ ${ }^{1}$ Department of Pathology, Division of Haematology, Faculty of Health Sciences, University of Cape Town, South Africa \\ ${ }^{2}$ National Health Laboratory Service, Groote Schuur and Red Cross War Memorial Children's Hospital, Cape Town, South Africa \\ ${ }^{3}$ Department of Molecular Medicine and Haematology, Faculty of Health Sciences, University of the Witwatersrand, Johannesburg, South Africa \\ ${ }^{4}$ National Health Laboratory Service, Johannesburg, South Africa
}

Corresponding author: J Bailly (jeniquebailly@gmail.com)

Background. Pregnant patients with Factor V Leiden (FVL) mutation are at an increased risk of venous thromboembolic disease (VTED) and placental-mediated complications. Thromboprophylaxis with low-molecular-weight heparin (LMWH) can potentially mitigate these risks.

Objective. To describe the clinical course of a cohort of patients with FVL mutation with different underlying genotypes.

Methods. The pregnancy outcomes, occurrence of VTED events and laboratory test results of pregnant women with FVL mutation managed at a quaternary medical centre over a period of 18 years in Johannesburg, South Africa, were analysed.

Results. Over the period of analysis, 25 pregnant women with FVL mutation were referred to the haematology department for management. Ten patients (40\%) had a family history, and 15 patients $(60 \%)$ a personal history of VTED. The majority of provoked VTED events (90\%) were secondary to combined oral contraceptive exposure. Previous pregnancy loss occurred in 4 (16\%) patients, of whom 3 (75\%) suffered recurrent losses. All women received prophylactic anti-Factor Xa (anti-FXa) dose-adjusted LMWH during anteand postnatal periods. All pregnancies resulted in live births with 1 VTED event recorded.

Conclusion. Patients with FVL mutation show phenotypical heterogeneity in terms of pregnancy outcomes, VTED events and placentalmediated complications. Confounders contributing to the heterogeneity are not completely defined and deciding on appropriate treatment is not fully standardised but the live birth rate is encouraging.

S Afr J Obstet Gynaecol 2020;26(1):8-12. https://doi.org/10.1796/SAJOG.2020.v26.11.1517

Factor V Leiden (FVL) is an autosomal dominantly inherited thrombophilic condition. The underlying mutational defect, a single nucleotide substitution, gives rise to an amino acid change in coagulation Factor V (FV), resulting in resistance to inactivation by the activated protein C-protein S complex, a natural anticoagulant system. Therefore, activated FV (FVa) together with coagulation Factor X (FX) has unregulated prothrombinase activity with resultant thrombin generation and fibrin clot formation. ${ }^{[1,2]}$ The normal inactivation of $\mathrm{FVa}$, and its subsequent role within the natural anticoagulant system to control fibrin clot formation, is depicted in Fig. 1..$^{[2]}$

FVL is the most common inherited thrombophilic condition in patients of northern European descent and is associated with a significantly increased risk of venous thromboembolic disease (VTED) ${ }^{[3]}$ Phenotypical presentation varies markedly and predictive markers for first thrombotic event have not been fully elucidated. However, the odds ratio for thrombotic complications depends on the underlying genotype (heterozygosity, homozygosity and compound heterozygosity) as well as the presence of pregnancy, exposure to combined oral contraceptive therapy and other thrombophilic conditions. A family and personal history of VTED can also be predictive of future thrombotic events. ${ }^{[4,5]}$

Pregnancy is a hypercoagulable state that fulfills all three components of Virchow's prothrombotic triad (Fig. 2) with a 10- to 20 -fold increased risk of VTED. This risk is even higher in patients with underlying FVL mutation or other thrombophilic states. ${ }^{[6,7]}$ Furthermore, the risk of placental-mediated complications such as recurrent pregnancy loss, hypertensive disorders, abruptio placentae and intra-uterine growth restriction are also significantly increased in women with this mutation. ${ }^{[3,7]}$ Thromboprophylaxis during the ante- and postnatal periods is therefore common practice to protect against these complications. ${ }^{[7,8]}$

The use of fixed-dose low-molecular-weight heparin (LMWH) thromboprophylaxis has been associated with treatment failure with increased morbidity and mortality related to thrombotic events. ${ }^{[9]} \mathrm{A}$ recent publication from our centre regarding the safety and efficacy of anti-Factor Xa (anti-FXa) adjusted LMWH in pregnant patients at risk of VTED suggests that LMWH should be monitored and doseadjusted during pregnancy and the postpartum period. ${ }^{\left[{ }^{[}\right]}$

The current case series describes the clinical course of a cohort of patients with FVL mutation with different underlying genotypes, namely heterozygous or homozygous FVL mutation as well as compound heterozygosity for FVL mutation with another prothrombotic mutation. These patients received anti-FXa adjusted LMWH during pregnancy and postpartum to protect against VTED and/or recurrent pregnancy loss.

\section{Methods}

This was a single-centre retrospective, observational analysis of pregnant women with increased risk of VTED referred to the 


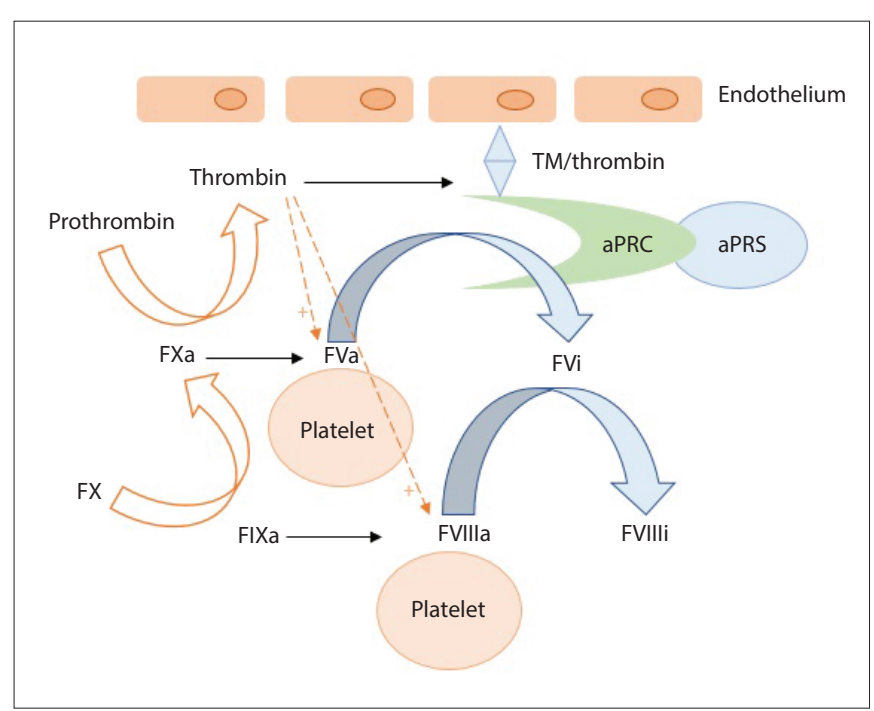

Fig. 1. A schematic representation of the inactivation of FVa by the activated Protein C-Protein S complex. aPRC is a naturally occurring anticoagulant that functions as a serine protease in the inactivation of FVa and FVIIIa to the inactivated forms, FVi and FVIIIi. PRC binds an endothelial receptor which aligns PRC with the TM/ thrombin complex allowing for its activation. aPRC binds free aPRS prior to exerting its enzymatic function. FVa functions as a co-factor for FXa within the prothrombinase complex. This complex activates prothrombin to thrombin which back-activates numerous clotting factors, including FV and FVIII, but also binds thrombomodulin after which it functions to activate PRC. FVIIIa functions as a co-factor for FIXa to form the tenase complex which results in the activation of more FX terminating in the formation of fibrin blood clot $^{[2]}$ $(a P R C=$ activated Protein $C ; a P R S=$ activated Protein $S$; $F X a=$ activated Factor $X ; F V=$ Factor $V ; F V i=$ inactivated Factor $V$; $F X=$ Factor $X ; F I X a=$ activated Factor IX; FVIII = Factor VIII; FVIIIi = inactivated FVIII; PRC = Protein $C ; T M=$ thrombomodulin).

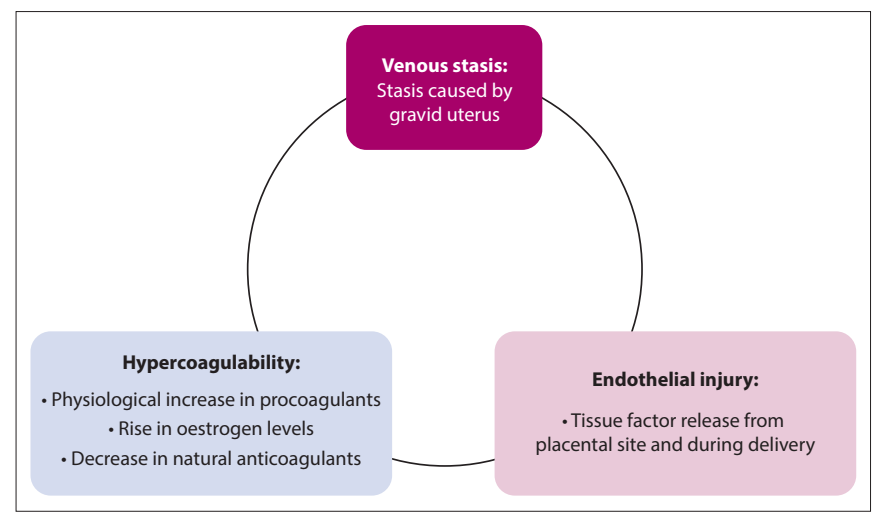

Fig. 2. Schematic presentation of Virchow's Triade as pertaining to normal pregnancy. ${ }^{[3]}$

haematology department at Charlotte Maxeke Johannesburg Academic Hospital in South Africa (SA). We collected data for all pregnant patients at risk of VTED referred for management to the department over a period of 18 years (January 1999 - May 2017). This cohort included a subset of patients with FVL mutation. Ethics approval for the study was obtained from the University of the Witwatersrand Human Research Ethics Committee (ref. no.
M170527). Owing to the retrospective nature of the study which reviewed the outcome of routine care, individual patient consent was not obtained.

The data that were analysed included patient demographics, personal and family history of thromboses, obstetric history, gestational age at which LMWH was commenced, $D$-dimer and anti-FXa levels as well as pregnancy outcomes and occurrence of VTED, pregnancy loss and abnormal bleeding.

VTED was defined as a non-compressible venous segment on ultrasound and/or the presence of pulmonary embolus on computed tomography scan of the pulmonary arteries or ventilation-perfusion scan. Pregnancy loss was defined as a miscarriage in any trimester, including stillbirth.

Descriptive statistics are presented as either means with standard deviations (SD) if normally distributed, or as medians with the lowest and the highest value if not normally distributed. Percentages are presented for discrete variables. Statistical analysis was done using GraphPad Prism version 8.1.2 (GraphPad Software, USA).

\section{Results}

Data for 25 patients diagnosed with FVL mutation were reviewed and pregnancy outcomes for a total of 33 pregnancies recorded. The majority of the patients were white $(88 \%)$ with $2(8 \%)$ patients of Indian and 1 patient (4\%) of mixed ethnicity. Twenty-one (85\%) patients were heterozygous for the FVL mutation, 2 (8\%) were homozygous and 2 patients (8\%) had compound heterozygosity (Table 1).

Ten patients (40\%) reported a family history of VTED in firstand/or second-degree relatives, 15 patients $(60 \%)$ had a personal history of VTED with 2 (8\%) reported as unprovoked and 10 (40\%) as provoked events. The majority of the provoked events (90\%) were secondary to combined oral contraceptive (COC) drug exposure. Only 1 patient (4\%) reported spontaneous recurrent VTED after combined oral contraceptive (COC) drug cessation.

Previous pregnancy loss was reported for 4 patients (16\%). One patient suffered a total of 3 , and a second patient 2 previous pregnancy losses. The gestational ages at which these prior events occurred were not recorded and an underlying obstetric cause could not be determined from the doctor's patient consultation notes.

All 25 patients with FVL mutation were commenced on LMWH prophylaxis antenatally at a dose of $0.5 \mathrm{mg} / \mathrm{kg}$. The gestational age at which LMWH was started varied and largely depended on the time of referral, underlying prothrombotic genotype, previous pregnancy outcomes and a personal or family history of VTED (Table 1).

As a sensitive indicator of in vivo fibrin clot formation and breakdown, $D$-dimer levels were obtained at first consultation and repeated together with an anti-FXa level within 1 week of commencing prophylactic LMWH therapy. A normal D-dimer level at our centre is $<0.25 \mathrm{mg} / \mathrm{L}$. These initial results, as well as subsequent follow-up results guided LMWH dose adjustment aiming for anti-FXa activity within the prophylactic range of 0.2 - $0.6 \mathrm{IU} / \mathrm{dl}$ (Fig $3 \mathrm{~A}$ - D). LMWH was stopped 24 hours prior to planned delivery. Ninety-seven percent of patients underwent elective caesarean section deliveries with one of the 33 pregnancies resulting in a spontaneous vaginal delivery at term.

Only 1 twin pregnancy was recorded in this case series (patient 2, Table 1). The patient was nulliparous with a personal and family history of VTED. She had a normal body mass index (BMI), 


\section{RESEARCH}

Table 1. Patient characteristics and pregnancy outcomes

\begin{tabular}{|c|c|c|c|c|c|c|c|c|}
\hline Patient & Diagnosis & Age & Ethnicity & $\begin{array}{l}\text { Gravity }(G) \text {, parity } \\
(P) \text { in current } \\
\text { pregnancy }\end{array}$ & $\begin{array}{l}\text { Gestational age at } \\
\text { initiation of } \mathrm{LMWH}\end{array}$ & Previous VTED & $\begin{array}{l}\text { Family } \\
\text { VTED } \\
\text { history } \\
\end{array}$ & $\begin{array}{l}\text { Current } \\
\text { pregnancy } \\
\text { outcome } \\
\end{array}$ \\
\hline 1 & $\begin{array}{l}\text { Heterozygous } \\
\text { FVL mutation }\end{array}$ & 29 & White & G1P0 & $19 \mathrm{w}$ & No & Yes & $\begin{array}{l}\text { No VTED, live } \\
\text { birth }\end{array}$ \\
\hline 2 & $\begin{array}{l}\text { Heterozygous } \\
\text { FVL mutation }\end{array}$ & 31 & White & G1P0 & $10 \mathrm{w}$ & Post-surgery DVT & Yes & $\begin{array}{l}\text { No VTED, live } \\
\text { birth }\end{array}$ \\
\hline 4 & $\begin{array}{l}\text { Heterozygous } \\
\text { FVL mutation }\end{array}$ & 38 & White & G1P0 & $16 \mathrm{w}$ & Yes (unprovoked) & Yes & $\begin{array}{l}\text { No VTED, live } \\
\text { birth }\end{array}$ \\
\hline 5 & $\begin{array}{l}\text { Heterozygous } \\
\text { FVL mutation }\end{array}$ & 46 & Indian & G2P1 & $9 \mathrm{w}$ & No & Yes & $\begin{array}{l}\text { No VTED, live } \\
\text { birth }\end{array}$ \\
\hline 6 & $\begin{array}{l}\text { Homozygous } \\
\text { FVL mutation }\end{array}$ & 34 & White & G1P0 & Pre-conception IVF & Yes & No & $\begin{array}{l}\text { No VTED, live } \\
\text { birth }\end{array}$ \\
\hline 7 & $\begin{array}{l}\text { Heterozygous } \\
\text { FVL mutation }\end{array}$ & 33 & White & G2P1 & $5 \mathrm{w}$ & Yes (unprovoked) & Yes & $\begin{array}{l}\text { Thrombo-phlebitis } \\
\text { ( } 27 \text { weeks) post } \\
\text { appendicitis, live } \\
\text { birth }\end{array}$ \\
\hline 8 & $\begin{array}{l}\text { Heterozygous } \\
\text { FVL mutation }\end{array}$ & $26,29^{+}$ & White & $\mathrm{G} 1 \mathrm{P} 0$ and $\mathrm{G} 2 \mathrm{P} 1$ & 20 and $15 \mathrm{w}$ & No & No & $\begin{array}{l}\text { No VTED, live } \\
\text { births }\end{array}$ \\
\hline 9 & $\begin{array}{l}\text { Heterozygous } \\
\text { FVL mutation }\end{array}$ & $35,39^{\dagger}$ & White & G1P0 and G2P1 & $23 \mathrm{w}$ and $21 \mathrm{w}$ & No & No & $\begin{array}{l}\text { No VTED, live } \\
\text { births }\end{array}$ \\
\hline 10 & $\begin{array}{l}\text { Heterozygous } \\
\text { FVL mutation }\end{array}$ & 38 & White & G3P1M1 & $16 \mathrm{w}$ & Yes (unprovoked) & No & $\begin{array}{l}\text { No VTED, live } \\
\text { birth }\end{array}$ \\
\hline 11 & $\begin{array}{l}\text { Homozygous } \\
\text { FVL mutation }\end{array}$ & $35,37^{\dagger}$ & White & $\mathrm{G} 1 \mathrm{P} 0$ and $\mathrm{G} 2 \mathrm{P} 1$ & $\begin{array}{l}\text { At conception with } \\
\text { IVF and } 16 \mathrm{w}\end{array}$ & VTED on COC & No & $\begin{array}{l}\text { No VTED, live } \\
\text { births }\end{array}$ \\
\hline 12 & $\begin{array}{l}\text { Heterozygous } \\
\text { FVL mutation }\end{array}$ & 35 & White & $\mathrm{G} 2 \mathrm{P} 1$ & $16 \mathrm{w}$ & No & No & $\begin{array}{l}\text { No VTED, live } \\
\text { birth }\end{array}$ \\
\hline 13 & $\begin{array}{l}\text { Heterozygous } \\
\text { FVL mutation }\end{array}$ & $25,27,32^{\dagger}$ & White & G1P0, G2P1, G3P2 & $25 \mathrm{w}, 12 \mathrm{w}, 17 \mathrm{w}$ & No & Yes & $\begin{array}{l}\text { No VTED, live } \\
\text { births }\end{array}$ \\
\hline 15 & $\begin{array}{l}\text { Heterozygous } \\
\text { FVL mutation }\end{array}$ & 34 & White & G1P2 & $15 \mathrm{w}$ & VTED on COC & Yes & $\begin{array}{l}\text { No VTED, live } \\
\text { births }^{\star}\end{array}$ \\
\hline 16 & $\begin{array}{l}\text { Heterozygous } \\
\text { FVL mutation }\end{array}$ & $30,33,34^{\dagger}$ & White & G1P0, G2P1, G3P2 & $34 \mathrm{w}, 35 \mathrm{w}, 24 \mathrm{w}$ & No & No & $\begin{array}{l}\text { No VTED, live } \\
\text { births }\end{array}$ \\
\hline 17 & $\begin{array}{l}\text { Compound } \\
\text { heterozygous: } \\
\text { FVL and } \\
\text { Prothrombin } \\
\text { G20210A }\end{array}$ & 32 & White & G2P1 & $8 \mathrm{w}$ & No & No & $\begin{array}{l}\text { No VTED, live } \\
\text { birth }\end{array}$ \\
\hline 18 & $\begin{array}{l}\text { Heterozygous } \\
\text { FVL mutation }\end{array}$ & 32 & White & G4P0M3 & $10 \mathrm{w}$ & No & No & $\begin{array}{l}\text { No VTED, live } \\
\text { birth }\end{array}$ \\
\hline 19 & $\begin{array}{l}\text { Heterozygous } \\
\text { FVL mutation }\end{array}$ & 36 & White & G3P0M1, TOP1 & $12 \mathrm{w}$ & VTED on COC & No & $\begin{array}{l}\text { No VTED, live } \\
\text { birth }\end{array}$ \\
\hline 20 & $\begin{array}{l}\text { Heterozygous } \\
\text { FVL mutation }\end{array}$ & 32 & White & G2P0, TOP1 & $6 \mathrm{w}$ & VTED on COC & Yes & $\begin{array}{l}\text { DVT at } 8 \text { weeks on } \\
\text { LMWH, live birth }\end{array}$ \\
\hline 21 & $\begin{array}{l}\text { Heterozygous } \\
\text { FVL mutation }\end{array}$ & 32 & White & G3P0M2 & $16 \mathrm{w}$ & VTED on COC & No & $\begin{array}{l}\text { No VTED, live } \\
\text { birth }\end{array}$ \\
\hline 22 & $\begin{array}{l}\text { Heterozygous } \\
\text { FVL mutation }\end{array}$ & $29,32^{+}$ & Indian & G1P0, G2P1 & $8 \mathrm{w}, 8 \mathrm{w}$ & VTED on COC & No & $\begin{array}{l}\text { No VTED, live } \\
\text { birth }\end{array}$ \\
\hline 23 & $\begin{array}{l}\text { Heterozygous } \\
\text { FVL mutation, } \\
\text { varicosities }\end{array}$ & 35 & White & G3P2 & $34 \mathrm{w}$ & No & No & $\begin{array}{l}\text { No VTED, live } \\
\text { birth }\end{array}$ \\
\hline 24 & $\begin{array}{l}\text { Heterozygous } \\
\text { FVL mutation, } \\
\text { varicosities }\end{array}$ & 31 & White & G3P2 & $34 \mathrm{w}$ & VTED on COC & No & $\begin{array}{l}\text { No VTED, live } \\
\text { birth }\end{array}$ \\
\hline 25 & $\begin{array}{l}\text { Heterozygous } \\
\text { FVL mutation }\end{array}$ & 33 & White & G3P1M1 & $14 \mathrm{w}$ & VTED on COC & Yes & $\begin{array}{l}\text { No VTED, live } \\
\text { birth }\end{array}$ \\
\hline
\end{tabular}




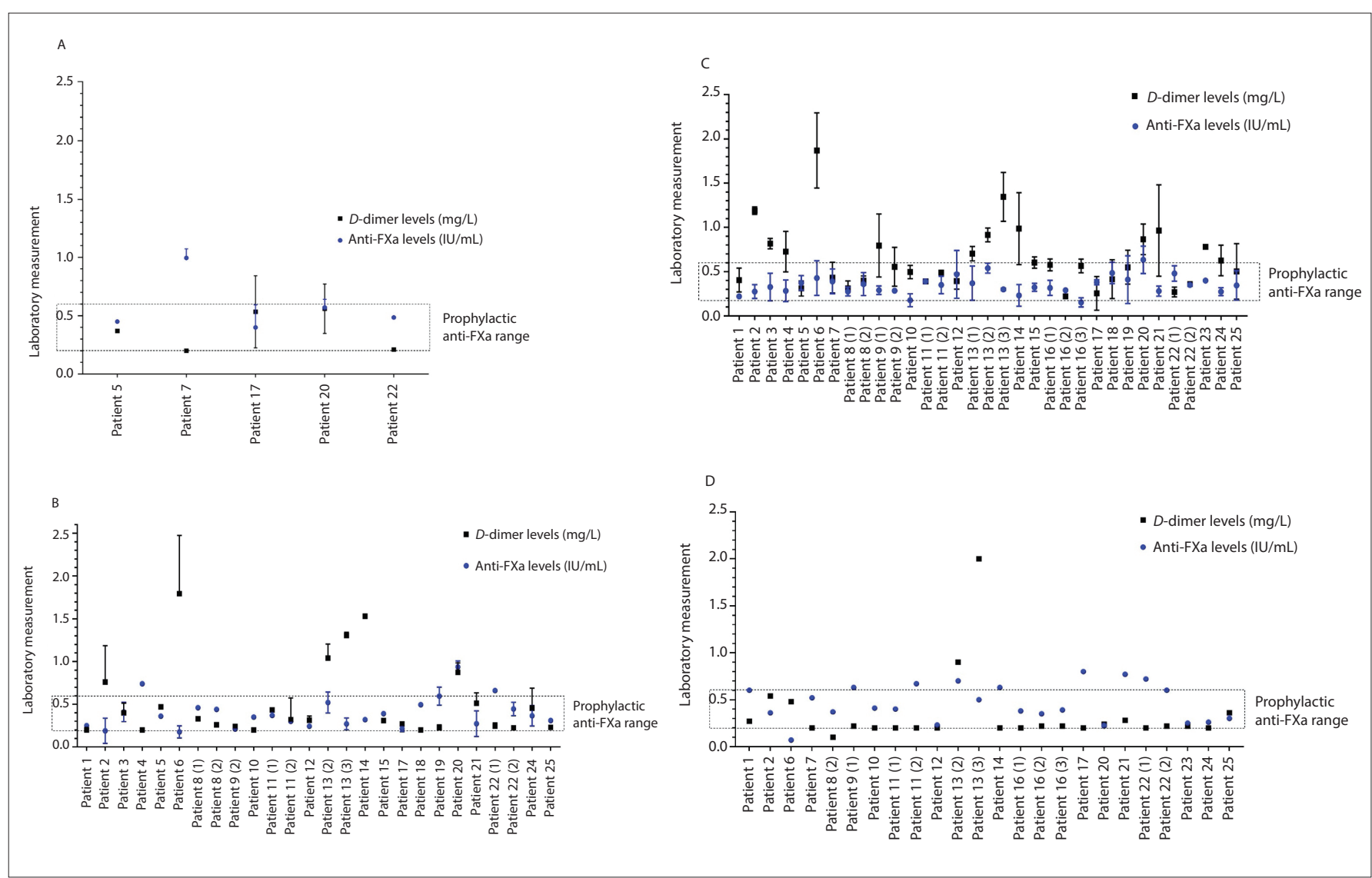

Fig. 3. D-dimer and anti-Factor Xa levels during the antenatal period of the first (A), second (B) and third (C) trimester, and during postpartum follow-up (D). Measurements for trimesters 1, 2 and 3 are presented as mean D-dimer and anti-Factor Xa levels with standard deviations (SD) if more than one measurement was obtained for that specific measurement period. Sequential pregnancies are annotated as (1) for the first pregnancy, (2) for the second, and (3) for the third pregnancy recorded. D-dimer levels were only available for 25 out of 33 pregnancies during the postpartum period because two patients defaulted follow-up and a further 6 patients had D-dimer measurements performed at a private laboratory.

normal renal function and no clinical evidence of VTED during her current pregnancy. Of note was markedly elevated $D$-dimer levels throughout pregnancy despite adequate anti-FXa activity levels. The mean (SD) D-dimer level during the second trimester was 1.19 $(0.42) \mathrm{mg} / \mathrm{L}$, and it remained at $1.19(0.04) \mathrm{mg} / \mathrm{L}$ during the third trimester. The $D$-dimer levels normalised post-delivery and LMWH thromboprophylaxis was stopped at 4 weeks postpartum.

Markedly raised $D$-dimer levels, despite adequate LMWH and no clinical features of VTED, were also observed during the second and third pregnancies in patient 13 (Table 1). The high $D$-dimer levels persisted postpartum despite the patient being clinically well with no clinical thrombotic complications, infection or bleeding.

Postpartum follow-up data were available for 31 pregnancies (93\%) as 2 patients defaulted from follow-up. D-dimer levels were only available for 25 out of the remaining 31 pregnancies during postpartum follow-up and this may be due to laboratory tests performed at a private laboratory not connected to CMJAH. Postpartum thromboprophylaxis was prescribed for 4 to 6 weeks postpartum or until normalisation of $D$-dimer levels. The median $D$-dimer levels with the lowest and the highest value recorded for each trimester are shown in Fig. 4. Maternal follow-up clinical examination records were recorded for up to 1 year post delivery.

VTED events occurred in 1 patient (prevalence of 3\%). The patient was heterozygous for FVL mutation and had a personal and family history of VTED. She developed a deep vein thrombosis (DVT) in the antenatal period. This event was recorded in the first trimester, 2 weeks after commencing LMWH and occurred despite adequate anti-FXa activity levels.

One patient developed acute appendicitis at 23 weeks' gestation and underwent an appendectomy which was complicated by thrombophlebitis of the greater saphenous vein 1 week post surgery. An ultrasound investigation did not reveal extension of the thrombus but the dose of LMWH was increased to $1 \mathrm{mg} / \mathrm{kg}$ twice a day for the remainder of her pregnancy and continued at a prophylactic dose for 6 weeks postpartum.

None of the patients suffered pregnancy loss while on anti-FXa dose-adjusted LMWH despite previous pregnancy loss reported in 4 patients. Heparin-induced thrombocytopenia (HIT) did not occur in any of these patients.

\section{Discussion}

Pregnant patients with FVL mutation are at an increased risk of VTED and placental mediated complications. Predictors for VTED complications in this group has not been fully elucidated but relate to a complex interplay between genetics, the environment and other risk factors. Women with homozygous FVL mutation, compound heterozygosity for FVL mutation and Prothrombin G20210A mutation, antithrombin deficiency, previous estrogen therapy-related 


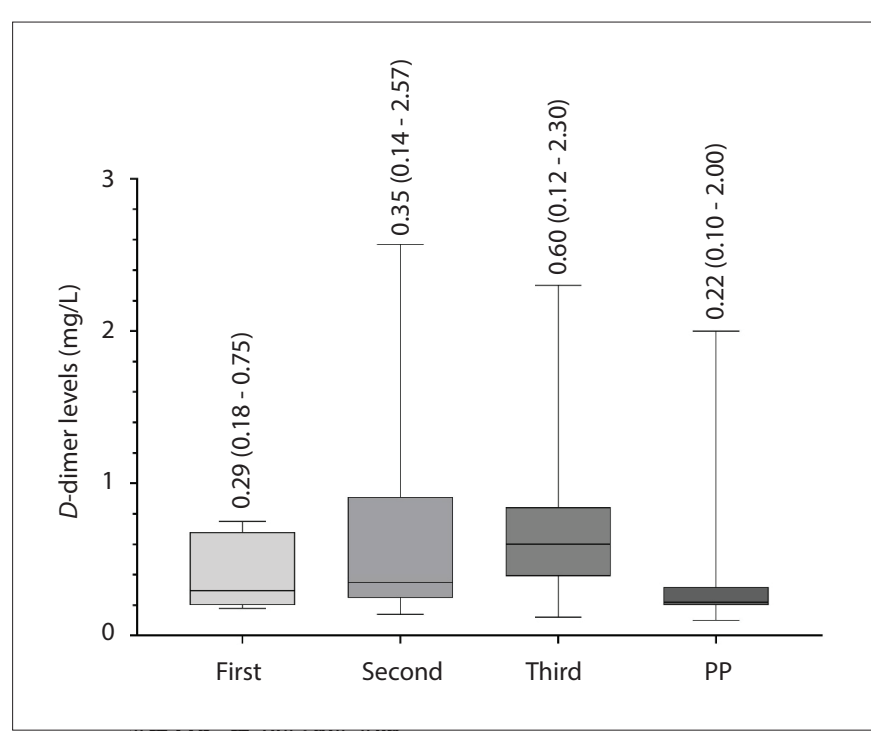

Fig. 4. The median D-dimer levels with the lowest and the highest value recorded for each of the first, second and third trimesters and postpartum. First trimester, $\mathrm{n}=10$; second trimester, $\mathrm{n}=50$; third trimester, $\mathrm{n}=92$; postpartum, $\mathrm{n}=25$.

VTE and a personal and family history of VTED are, however, strong predictors of thrombosis occurrence..$^{[5,8]}$

This case series highlights the phenotypic heterogeneity of patients with FVL mutation and in particular patients with heterozygosity for the mutation. Three patients (12\%) in this subgroup with heterozygous FVL mutation reported only a family history of VTED and 1 patient had a previous uncomplicated pregnancy for which she did not receive thromboprophylaxis. Four of the 6 patients with heterozygous FVL mutation (66\%) with a personal but no family history of VTED previously experienced provoked VTED in relation to COC use. The remaining 2 reported events (33\%) were considered unprovoked. One patient with compound heterozygosity for FVL and Prothrombin G20210 mutations did not report a personal or a family history of VTED despite a previous pregnancy for which she did not receive thromboprophylaxis.

Owing to the phenotypic heterogeneity in patients with FVL mutation, the gestational age at which thromboprophylaxis should be commenced is not established. In the present case series, patients were started on antenatal LMWH thromboprophylaxis at the time of referral from local obstetricians which varied markedly. Patients on lifelong anticoagulation with oral anticoagulation such as coumarinbased therapy were, however, commenced on prophylactic LMWH pre-conception to prevent exposure of the embryo to these mutagenic agents.

\section{Conclusion}

Patients with FVL mutation should receive LWMH thromboprophylaxis in the postpartum period but the use during pregnancy is not standardised and is dictated by the underlying genotype, personal and family history of VTED and history of recurrent pregnancy loss. Guidelines developed from ongoing clinical studies are needed to ensure correct risk stratification and optimal antenatal thromboprophylaxis in pregnant patients with FVL mutation.

Declaration. None.

Acknowledgements. None.

Author contributions. JB, SL and BJ were involved in the conception and design of the case series. JB wrote the article. SL and BJ revised the article. All authors approved the final version of the manuscript.

Funding. None.

Conflicts of interest. None.

1. Van Cott EM, Khor B, Zehnder JL. Factor V Leiden. Am J Hematol 2016;91(1):46-49. https://doi org/10.1002/ajh.24222

2. Dahlback B, Villoutreix BO. Regulation of blood coagulation by the protein C anticoagulant pathway: Novel insights into structure-function relationships and molecular recognition. Arterioscler Thromb Vasc Biol 2005;25(7):1311-1320. http://doi.org/10.1161/01.ATV.0000168421.13467.82

3. Bloomenthal D, von Dadelszen P, Liston R, Magee L, Tsang P. The effect of factor V Leiden carriage on maternal and fetal health. CMAJ 2002;167(1):48-54.

4. Franchini M, Mannucci PM. Interactions between genotype and phenotype in bleeding and thrombosis. Haematologica 2008;93(5):649-652. http://doi.org/10.3324/haematol.12356

5. Gerhardt A, Scharf RE, Greer IA, Zotz RB. Hereditary risk factors for thrombophilia and probability of venous thromboembolism during pregnancy and the puerperium. Blood 2016;128(19):23432349. http://doi.org/10.1182/blood-2016-03-703728

6. Bailly J, Jacobson BF, Louw S. Safety and efficacy of adjusted-dose enoxaparin in pregnant patients with increased risk for venous thromboembolic disease. Int J Gynaecol Obstet 2019;145(1):70-75. http://doi.org/10.1002/ijgo.12764

7. Simcox LE, Ormesher L, Tower C, Greer IA. Thrombophilia and pregnancy complications. Int J Mol Sci 2015;16(12):28418-28428. http://doi.org/10.3390/ijms161226104

8. Bates SM, Greer IA, Middeldorp S, Veenstra DL, Prabulos AM, Vandvik PO. VTE, thrombophilia, antithrombotic therapy, and pregnancy: Antithrombotic therapy and prevention of thrombosis, 9th ed: American College of Chest Physicians Evidence-Based Clinical Practice Guidelines. Chest 2012;141(2 Suppl):e691S-e736S.

9. Roeters van Lennep JE, Meijer E, Klumper FJ, Middeldorp JM, Bloemenkamp KW, Middeldorp S. Prophylaxis with low-dose low-molecular-weight heparin during pregnancy and postpartum: Is it effective? J Thromb Haemost 2011;9(3):473-480. http://doi/org/10.1111/j.1538-7836.2011.04186.x

Accepted 22 March 2020. 